\title{
Een databank van Oost-Vlaamse politici
}

Tony Valcke

\section{Citer ce document / Cite this document :}

Valcke Tony. Een databank van Oost-Vlaamse politici. In: Revue belge de philologie et d'histoire, tome 81, fasc. 2, 2003. Histoire medievale, moderne et contemporaine - Middeleeuwse. moderne en hedendaagse geschiedenis. pp. 369-373; doi : https://doi.org/10.3406/rbph.2003.4731

https://www.persee.fr/doc/rbph_0035-0818_2003_num_81_2_4731

Fichier pdf généré le 17/04/2018 


\title{
Een databank van Oost-Vlaamse politici
}

\author{
Tony VALCKE \\ Provinciebestuur Oost-Vlaanderen
}

In 1991 startte de provincie Oost-Vlaanderen met een 'Historiografisch Project' dat tot doel had onderzoek te verrichten naar de geschiedenis van de provinciale instelling en haar beleidsmakers. Zoals de Oost-Vlaamse gouverneur Herman Balthazar, tevens buitengewoon hoogleraar aan de vakgroep Nieuwste Geschiedenis van de Universiteit Gent, het stelde, lag deze geschiedenis nog zo goed als braak $\left({ }^{1}\right)$. Het enige referentiewerk dat op dat ogenblik voorhanden was, was de tweedelige publicatie van Luc Schepens over de West-Vlaamse provincieraad $\left({ }^{2}\right)$. Het Oost-Vlaams initiatief leidde tot de publicatiereeks De fonteinen van de Oranjeberg. In het eerste deel, dat verscheen in 1993, werd naast het institutioneel kader, een belangrijke plaats ingeruimd voor de verkiezingsresultaten $\left(^{3}\right)$. Op basis van uitgebreid archiefonderzoek werd een chronologisch overzicht gegeven vanaf de eerste provincieraadsverkiezingen in september 1836, met per kieskanton vermelding van het aantal ingeschreven en opgekomen kiezers, het aantal geldig uitgebrachte stemmen, de eventuele tweede ronde en per verkozene het aantal voorkeurstemmen en de lijst of partij waarvoor de persoon verkozen was. Precies met het oog op dit onderzoek en het verzamelen van alle relevante data werd gestart met een historische databank. Deze bewees vooral ook haar nut voor het tweede deel van De fonteinen van de Oranjeberg, meer bepaald het uitgebreid biografisch repertorium en de prosopografische analyse van de bijeengebrachte gegevens $\left({ }^{4}\right)$. In deze bijdrage gaan we wat dieper in op de gehanteerde werkwijze, de geraadpleegde bronnen en de problemen of knelpunten waarmee we geconfronteerd werden.

(1) H. BALTHAZAR, De provincie 1836-1986. Meer bedenken dan herdenken, Gent, Provinciebestuur Oost-Vlaanderen, 1986, 22 p. (Toespraak tot de provincieraad 23 september 1986).

(2) L. SCHEPENS, De provincieraad van West-Vlaanderen 1836-1921. Socio-politieke studie van een instelling en haar leden, met 501 biografieën van Westvlaamse notabelen, Tielt-Amsterdam, Lannoo, 1976, 655 p.; L. SCHEPENS, De provincieraad van WestVlaanderen. Deel II: 1921-1978. Socio-politieke studie van een instelling en haar leden, met 550 biografieën van Westvlaamse prominenten, Tielt-Amsterdam, Lannoo, 1979, $427 \mathrm{p}$.

(3) N. LeHOUCQ \& T. VALCKE, De fonteinen van de Oranjeberg. Politiek-institutionele geschiedenis van de provincie Oost-Vlaanderen van 1830 tot nu. Deel 1. De instelling. de bevoegdheden en de verkiezingsresultaten, Gent, Provinciebestuur Oost-Vlaanderen-Stichting Mens en Kultuur, 1993, 404 p.; Deel 2. Biografisch repertorium. Gent, Provinciebestuur Oost-Vlaanderen-Stichting Mens en Kultuur, 1997, 452 p.

(4) N. LeHOUCQ \& T. VALCKE, De fonteinen van de Oranjeberg. Deel 2, op. cit. 
Hoewel de verkiezingsresultaten het vertrekpunt vormden, gaat het in de eerste plaats om een personendatabank met gegevens over gouverneurs, gedeputeerden, provincieraadsleden en provinciegriffiers (1.412 personen). De databank bevat enkel gegevens over personen die hun mandaat effectief hebben uitgeoefend, de massa van kandidaten die het niet haalden zijn er niet in opgenomen. We kunnen de gegevens grosso modo in twee categorieën opsplitsen. Enerzijds zijn er de strikt persoonsgebonden gegevens zoals familienaam, voornaam, roepnaam (met aandacht voor eventueel afwijkende schrijfwijze), geboorteplaats en -datum, overlijdensplaats en -datum, studies (plaats, instelling en jaartal) en beroep, daarnaast naam, beroep en eventueel politieke mandaten van ouders, echtgenoot of partner(s) (inclusief summiere biografische data). Anderzijds zijn er de electorale of mandaatgebonden gegevens. Deze zijn opgesplitst in het provinciaal mandaat (begin- en einddatum van het mandaat, reden voor het beëindigen van het mandaat, verkiezingsdata en voorkeurstemmen, kiesomschrijving, politieke strekking, partij, functie in het bureau) en de eventuele andere politieke mandaten op gemeentelijk, regionaal, nationaal/federaal of internationaal niveau $\left({ }^{5}\right)$.

De historische databank is ook actueel. Aanvullingen of wijzigingen van gegevens worden op permanente basis bijgehouden. Zo zijn onder meer de gegevens verwerkt van de verkozenen bij de recentste verkiezingen (oktober 2000), van de opvolgers tussen twee verkiezingen in, alsook de wijzigingen in bijvoorbeeld lokale mandaten of het overlijden van oud-raadsleden.

Zoals reeds vermeld, vormden de verkiezingsdossiers, bewaard in het rijksarchief of het provinciaal archief, de basisbron. Deze bron leverde niet alleen de namen van de verkozenen en het aantal voorkeurstemmen op, maar dikwijls ook aanvullende biografische gegevens. In de ideale situatie treft men er naast de eigenlijke processen-verbaal van de provincieraadsverkiezingen namelijk ook de kandidatenlijsten (met vermelding van naam, beroep, adres of woonplaats en geboortedatum of -jaar) en de zogenaamde 'geloofsbrieven' aan, m.n. een uittreksel uit de geboorteakte of een bewijs van woonst. Die maakten dan weer verdere opzoekingen mogelijk. Jammer genoeg lijkt de bronnensituatie - zeker voor de $19 \mathrm{e}$ eeuw - verdacht veel op Zwitserse kaas met grote gaten. Zeker tot 1870 ontbreken de processen-verbaal (pv's) van de verkiezingen dikwijls of zijn de verkiezingsdossiers zeer onvolledig bewaard gebleven. Bovendien bevatten ze geen aanwijzing over de partijbenamingen (die we in de officiële bronnen pas aantreffen vanaf 1977). Daardoor waren we aangewezen op andere bronnen om de verkiezingen als het ware te reconstrueren (ut infra). Het provinciaal archief is een schatkamer voor electorale gegevens. Naast de eigenlijke verkiezingsdossiers zelf treft men er ook dossiers aan naar aanleiding van klachten bij verkiezingen of documenten (bijvoorbeeld lijsten met verkozenen per kieskanton/-district) die ten behoeve van de administratie werden opgemaakt. Vanaf de jaren 1970

(5) Voor meer info, zie: N. LEHOUCQ \& T. VALCKE, De fonteinen van de Oranjeberg. Deel 2, op. cit., p. 118-129. 
van de $20^{\mathrm{e}}$ eeuw konden we gebruikmaken van de door het provinciebestuur gepubliceerde resultaten van de verkiezingen (zie ook de publicaties door het ministerie van Binnenlandse Zaken). Voor de jaren dat we hierop een beroep deden, vond een steekproefcontrole plaats in de originele pv's.

Het mag duidelijk zijn dat aanvulling en controle van deze informatie noodzakelijk was. Onontbeerlijk zijn de processen-verbaal van de zittingen van de provincieraad (verder pvpr). De verkiezingen werden/worden immers (al dan niet) geldig verklaard door de provincieraad, waarbij het meermaals voorviel dat de rechtstreeks verkozenen hun mandaat verzaakten. Om maar één voorbeeld te noemen: Herman De Croo werd diverse keren rechtstreeks verkozen, maar nam nooit een mandaat op in de Oost-Vlaamse provincieraad. Hij werd meteen op de installatievergadering vervangen door de eerste opvolger. Ook de gegevens met betrekking tot de leden van de bestendige deputatie (datum van verkiezing, aantal stemmen) werden uit de pvpr gehaald. Vervolgens werden de electorale gegevens - vooral voor de $19^{\mathbf{e}}$ eeuw - aangevuld en de hiaten opgevuld met krantenonderzoek. Hierbij werd ernaar gestreefd kranten van verschillende politieke strekkingen te raadplegen, bijvoorbeeld de katholieke Le Bien Public en La Flandre Libérale. Toch moet beklemtoond worden dat de provincieraadsverkiezingen steeds veel minder aandacht kregen dan de parlementsverkiezingen, waarmee ze goeddeels samenvielen ${ }^{6}$ ). Terwijl men voor de ene werkelijk moet gaan zoeken in de binnenbladzijden van de krant, waren de andere voorpaginanieuws. Dat gold a fortiori voor buitengewone verkiezingen (bijvoorbeeld ter vervanging van een overleden raadslid) in kleinere en landelijke kieskantons.

Voor de lokale mandaten werden op systematische wijze de registers geraadpleegd die per Oost-Vlaamse gemeente bijhouden welke gemeenteraadsleden, schepenen en burgemeesters in functie treden. Dit gebeurde vanaf 1830 tot heden en voor alle 297 gemeenten die Oost-Vlaanderen vóór de fusies telde.

Vervolgens werd uitgebreid archiefonderzoek verricht voor wat de persoonsgebonden informatie betreft. Zo werden ondermeer in de burgerlijke stand van diverse gemeenten de geboorte-, huwelijks- en/of overlijdensakten opgespoord. Ook werden biografische naslagwerken, kandidatuursoefeningen en bredere literatuur intensief doorgenomen. Een schat aan informatie werd gepuurd uit talrijke bijdragen in heemkundige tijdschriften. En tot slot vulden zowel de oud-provincieraadsleden als de nog actieve mandatarissen een inlichtingenfiche in. De praktijk leerde dat controle op de juistheid en volledigheid van de verstrekte informatie ook in dit geval niet overbodig was. Meer in het algemeen werd, indien de geraadpleegde literatuur op tegenstrijdigheden werd betrapt, zoveel mogelijk naar de oorspronkelijke bron teruggegrepen.

(6) N. LehoucQ \& T. VALCKE, De fonteinen van de Oranjeberg. Deel 1, op. cit., p. 354- 
Het resultaat van dit diepgaand biografisch onderzoek zijn uitgebreide biografische steekkaarten, gelinkt aan de verkiezingen. Met behulp van een goed gestructureerde databank is prosopografisch onderzoek mogelijk, zoals bijvoorbeeld in het vlak van verwantschappen tussen de politieke actoren.

De onderzoeksperiode is chronologisch alleen afgebakend door een terminus a quo, met name vanaf 1830 . Het kiessysteem heeft in deze tijdspanne zeer fundamentele wijzigingen ondergaan. Zo moet er omzichtig worden omgegaan met voorkeurstemmen naargelang het gaat om de periode van het meervoudig of enkelvoudig mannenstemrecht of de periode van het algemeen stemrecht voor vrouwen en mannen. Net als bij parlements- en gemeenteraadsverkiezingen was ook bij provincieraadsverkiezingen het systeem van partiële vernieuwing in zwang. Dit kwam er concreet op neer dat de provincieraad waarvoor in principe om de vier jaar verkiezingen werden gehouden, om de twee jaar voor de helft (van de kieskantons) werd vernieuwd. Buitengewone verkiezingen waren nodig wanneer raadsleden ontslag namen of overleden. Tot slot vonden er na belangrijke wetswijzigingen $(1848,1872,1894)$ ook integrale verkiezingen plaats waarbij de voltallige provincieraad werd vernieuwd. Niet onbelangrijk is verder dat het aantal raadsleden meerdere malen werd verhoogd (wat doorgaans aanleiding gaf tot een buitengewone verkiezing in één of meer kieskantons). De wet voorzag immers in een aanpassing aan het inwonertal van de provincie (in de praktijk gebeurde dit na de tienjaarlijkse volkstellingen). Vanaf 1921 werd dit voor een langere periode vastgelegd, maar tussentijds konden er zich wel nog verschuivingen voordoen tussen de verschillende kiesdistricten onderling $\left({ }^{7}\right)$. Deze zetelverschuivingen hadden zeker ook gevolgen voor de politieke strijd in kwestieuze kiesomschrijvingen.

Bij de interpretatie van de kiesresultaten is ook de invoering van de evenredige vertegenwoordiging (1899) heel belangrijk. Voor de provincieraadsverkiezingen gebeurde dat pas in 1921. In verband hiermee doet zich trouwens - althans in Oost-Vlaanderen - een opvallend verschijnsel voor. $\mathrm{Na}$ de invoering van het algemeen meervoudig stemrecht in 1894 bleef het meerderheidstelsel dus nog in gebruik. Het resultaat was een enorme toename van de zogenaamde verkiezingen 'zonder strijd' $\left({ }^{8}\right)$.

Een mogelijk discussiepunt vormen de termini van de mandaten. Als begindatum hanteerden wij in principe de datum van de provincieraadsverkiezingen. Tenzij het om een opvolging ging. In dat geval namen wij de datum waarop de opvolger in de provincieraad de eed aflegde. Juridisch wordt echter steeds de datum van eedaflegging beschouwd als het begin van het mandaat, maar het is praktisch haast onmogelijk dit 'historisch' na te gaan (de bronnen laten dit niet toe). Als einddatum geldt in principe de datum van de provincieraadsverkiezingen waarop het provincieraadslid ofwel niet herkozen werd ofwel geen kandidaat meer was. Andere mogelijkheden zijn:

(7) D. CONINCKX, H. REYNAERT \& T. VALCKE (red.), De provincieraden in Vlaanderen, Brugge, Vanden Broele, 2000, 368 p. (p. 95, 127 en 167).

(8) In 1894 in niet minder dan de helft van alle Oost-Vlaamse kieskantons! 
de verkiezingen voor Kamer, Senaat of Vlaams Parlement, de datum van ontslag of van overlijden.

Een specifiek probleem was dat van de 'niet verkozen mandatarissen'. Tijdens de Tweede Wereldoorlog werden enkele gedeputeerden aangesteld, die evenwel nooit bij de provincieraadsverkiezingen waren verkozen.

De onderzoeksresultaten werden in de eerste plaats toegankelijk gemaakt via de publicatiereeks De fonteinen van de Oranjeberg. Aangezien zowel intern (via de administratie) als extern regelmatig vragen werden gesteld m.b.t. de politieke vertegenwoordigers werd de historische databank via de provinciale website ter beschikking gesteld.

Op dit moment is slechts een gedeelte van de gegevens op deze manier ontsloten. Omwille van privacy-gevoeligheid werd immers besloten bepaalde gegevens (vooral m.b.t. ouders en huwelijk) niet via het web openbaar te maken. Illustratief voor deze gevoeligheid is dat een rechter er een probleem van maakte dat gepubliceerd zou worden dat hij ooit voor een bepaalde partij verkozen was.

Momenteel staan de volgende zoekmogelijkheden ter beschikking: eenvoudig op naam of gestructureerd op type mandaat, verkiezingsdatum, kiesomschrijving, geslacht en/of partij. Op aanvraag kan de volledige versie van de databank ter plaatse geconsulteerd worden. De mogelijkheid om na verloop van een zekere periode (bijvoorbeeld $\mathrm{x}$ aantal jaren na het overlijden van de betrokken politicus) de volledige versie vrij consulteerbaar te maken, staat ter discussie en kan op termijn leiden tot een uitgebreidere versie op de website.

Tot slot van deze bijdrage verwijs ik graag naar de resultaten van het collectieve project 'Provincieraden in Vlaanderen na 1945'. Vanuit de wetenschap dat een overzicht en analyse van de verkiezingsresultaten van alle (Vlaamse) provincies ontbrak, werd door prof. dr. H. Reynaert, drs. D. Coninckx en T. Valcke een gezamenlijk project opgezet. Het opzet bestond erin alle gegevens te verzamelen en een analyse te maken van de verkiezingen en de verkozenen voor alle Vlaamse provincieraden sinds de Tweede Wereldoorlog. Om vragen naar de partijpolitieke en sociaal-professionele samenstelling te kunnen beantwoorden, werden alle data in een databestand opgenomen. In totaal gaat het over 17 verkiezingsdata en 7.566 mandaten (inclusief de opvolgers). Bij de voorbereidingen werden we geconfronteerd met enkele specifieke problemen per provincie. De onderzoeksresultaten werden gepubliceerd $\left({ }^{9}\right)$, de verkiezingsuitslagen zelf niet.

(9) D. CONINCKX, H. ReYNAERT \& T. VAlCKe (red.), De provincieraden in Vlaanderen op. cit. 